\title{
Сучасні можливості запобігання впливу препаратів біотину на хід лабораторних досліджень
}

\section{В.М. Резніченко ${ }^{1}$, M.І. Бобрик ${ }^{2}$}

Державний заклад «Поліклініка № 2» ДуС

${ }^{2}$ Національний медичний університет імені О.О. Богомольця

За статистикою близько 70\% діагностичних лабораторних помилок зумовлено недотриманням правил на преаналітичному етапі. За результатами лабораторних обстежень лікар найчастіше приймає обгрунтоване рішення щодо діагнозу та подальшого лікування, тому помилки на лабораторному етапі необхідно виключати. Досягти максимальної точності результатів обстеження дозволить уважне ставлення до всіх ключових складових преаналітичного етапу.

2017 року вийшло повідомлення FDA про інтерферуючий вплив біотину на результати лабораторних досліджень і пов'язані із цим ризики для здоров’я. Проте поінформованість лікарів, співробітників лабораторій і пацієнтів щодо впливу високих доз біотину на найбільш поширені лабораторні тести наразі залишається низькою. FDA встановлено, що інтерференція біотину може бути причиною як завищених, так і занижених результатів залежно від технології дослідження (конкурентний імуно-

* Адреса для листування (Correspondence): Національний медичний університет імені О.О. Богомольця, бульвар Тараса Шевченка, 13, м. Київ, 01601, Україна. E-mail:zdovado@ukr.net

○ В.М. Резніченко, М.І. Бобрик аналіз - хибне завищення результату, неконкурентний імуноаналіз - хибне заниження результату). Період напіввиведення біотину становить 2-20 годин залежно від дози, натомість в одному з досліджень інтерференцію спостерігали впродовж 25 годин після одноразового введення 30 мг біотину, тоді як в іншому дослідженні кількість антитіл до рецептора ТТГ повернулася до нормального значення через 7 днів після закінчення біотинової терапії. Вплив біотину може залишитися невиявленим і призвести до викривлення результатів досліджень. Спотворені результати досліджень призводять до помилок діагностики та призначення некоректної терапії.

Конкретні приклади

- Помилковий біохімічний діагноз гіпертиреозу в імунотестах, що грунтуються на стрептавідин-біотині: проблема приймання біотину та пов'язаної із цим інтерференції. Clin Chem Lab Med 2016.

- Лікування біотином як причина помилкових результатів імунохімічних тестів: застереження для лікарів. Drug Discov \& Ther 2016. 
Актуальна інформація

- Хибна діагностика хвороби Грейвса внаслідок впливу біотину на імунотестування огляд клінічних випадків. J Clin Endocrinol Metab 2016.

- Хибна діагностика хвороби Грейвса з явним тяжким гіпертиреозом у пацієнтів, які приймають біотин у мегадозах. Thyroid 2016.

- За концентрації біотину в крові $\geq 5$ нг/мл результат дослідження тиреоглобуліну може мати хибне заниження до 10\% (за ще більшої концентрації біотину інтерференція може становити $>10 \%$ ). Помилково занижений рівень тиреоглобуліну, клінічно значущого біомаркера для моніторингу диференційованих форм тиреоїдного раку, може призвести до неможливості точної діагностики та потенційно серйозних клінічних наслідків, таких як невиявлення рецидиву, метастазування раку щитоподібної залози.

Біотин (вітамін $\mathrm{B}_{7}$, або Н) є водорозчинним вітаміном групи $\mathrm{B}$, який бере участь у процесах метаболізму білків, жирів і вуглеводів, засвоєння глюкози, розвитку плода, впливає на стан нервової системи, волосся, шкіри та нігтів. За недостатності біотину спостерігаються ураження шкіри верхніх і нижніх кінцівок, сухість і нездоровий відтінок шкіри, блідий гладенький язик, сонливість, депресія, болючість і слабкість м'язів, гіпотонія, підвищення рівнів холестерину та глюкози в крові, анемія, втрата апетиту та нудота, погіршення стану волосся.

Рекомендована щоденна доза біотину становить близько 30 мкг, проте:

- на сьогодні випускаються капсули із вмістом біотину 5-10 мг;

- клінічні дослідження свідчать про застосування високих доз біотину в лікуванні таких захворювань, як розсіяний склероз (100-300 мг);

- біотин міститься в мультивітамінах (3040 мкг), у спеціальних біотинових харчових домішках (5-10 мг), продуктах для підтримки стану нігтів, волосся та шкіри (5-40 мг).

Споживання біотину в усьому світі вивчено недостатньо, натомість дослідження в США показало, що воно зростає.

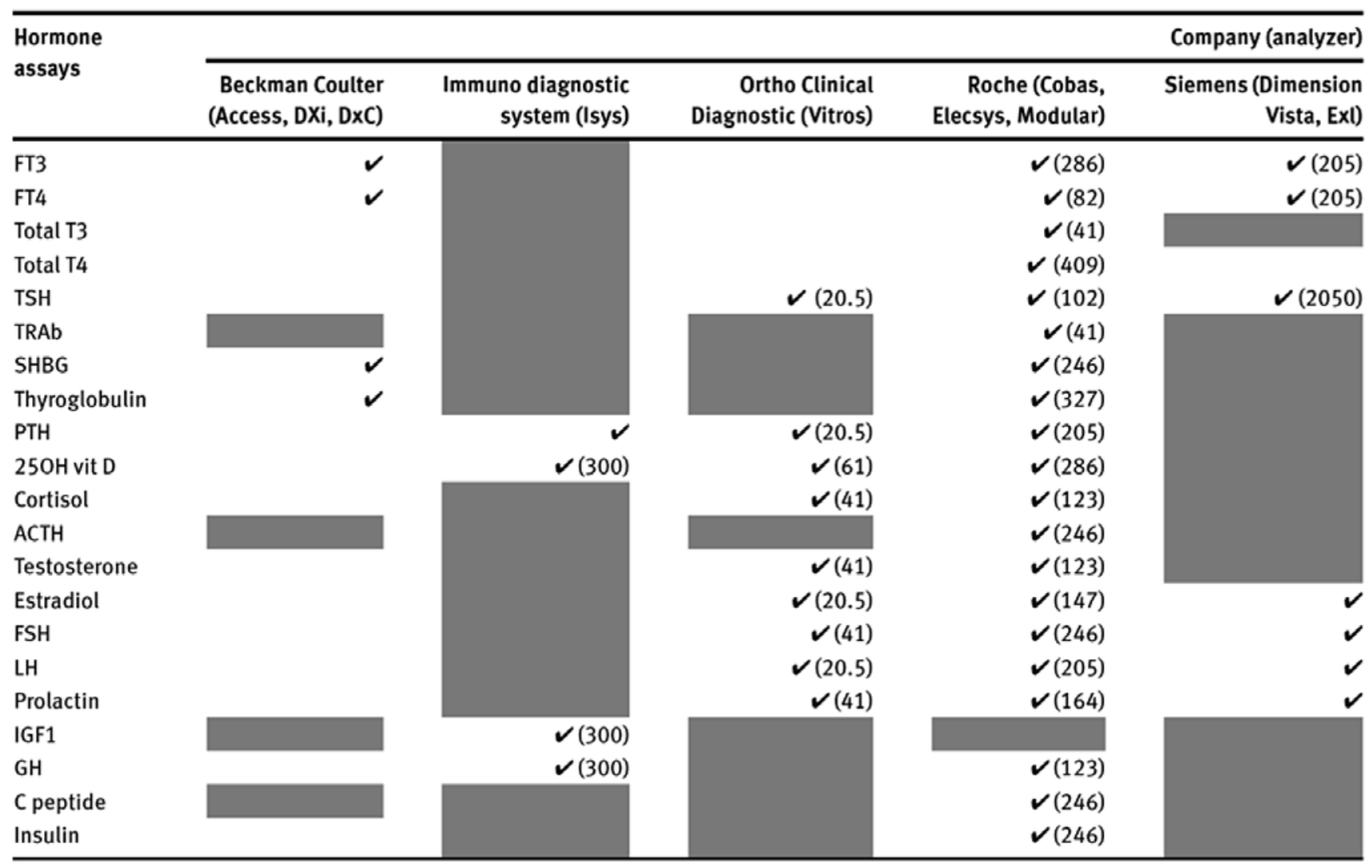

A “ $\checkmark$ " mark indicates that the streptavidin biotin interaction is used as immune complexes separation methodology. Biotin concentrations (nmol/L) above which an erroneous result can happen are indicated for each assay, when information is given in the reagent notices (i.e. concentration leading to bias above $\pm 10 \%$ of the target). In theory, the analytes for which erroneous results occur at the lowest biotin concentration, are those that will be most frequently impacted facing biotin supraphysiological intake. Dark rectangle, assay non available in the tests menu. 
Слід пам'ятати про вроджені порушення метаболізму біотину, які підвищують його концентрацію в крові до 5-20 мг.

Складність ситуації посилюється незнанням пацієнтів про вміст біотину в препаратах, які вони приймають. Лабораторії зазвичай не зможуть довідатися про вміст біотину в зразку. Лікарі прийматимуть рішення, які грунтуються на неправильних результатах досліджень. Причому метод «стрептавідин-біотин» $є$ поширеним методом, який використовується багатьма діагностичними компаніями.

\begin{tabular}{c|}
\hline На відміну від інших лабораторій, \\
у МЛ «ДІЛА» використовують методи, \\
що ВИКЛЮЧАЮть ВПЛИв БІОтИну \\
на результати визначення ТТГ, вільних $\mathrm{T}_{3} \mathrm{i} \mathrm{T}_{4}$ \\
\hline
\end{tabular}

Будь-який імуноаналіз із використанням методу «стрептавідин-біотин» може бути уразливий до дії біотину. Тобто, проблема інтерферуючого впливу препаратів біотину на результати лабораторних досліджень є поширеною, може залишатися не виявленою та несе ризики для здоров'я.

У рекомендаціях FDA 2017 року щодо запобігання інтерферуючому впливу препаратів біотину на хід лабораторних досліджень зазначено:

1. Слід виявляти на передлабораторному етапі пацієнтів, які приймають біотин.

2. Необхідно, аби пацієнти інформували лікаря про приймання препаратів, які містять біотин. Слід визначати, чи не вплине біотин на результат лабораторного обстеження.

3. Якщо пацієнт приймає біотин та інформував або не інформував лікаря, слід (за відсутності протипоказань) відмінити препарат біотину та через $\geq 7$ днів провести заплановане лабораторне дослідження.
4. Пацієнт може не знати про те, що він вживає препарат із біотином. На лабораторному етапі виявити зразки, що містять біотин, важко, тому лабораторії не зможуть дізнатися про вміст біотину в зразку біоматеріалу пацієнта, у результаті лікарі можуть приймати рішення, що грунтуються на неправильних результатах досліджень. Якщо результат лабораторного дослідження не відповідає клінічному стану обстежуваного, слід не виключати впливу біотину як можливого джерела помилки.

\section{Висновки}

- Біотин - важливий вітамін і домішка для здорового життя, яку широко використовують і лікарі, і пацієнти.

- Лабораторні тест-системи, що використовують метод «біотин-стрептавідин» (вільне захоплення), можуть бути чутливими до впливу біотину.

- НА ВІДМІНУ ВІД ІНШИХ ЛАБОРАТОРІЙ, у МЛ «ДІЛА» використовуються методи, що виключають вплив біотину на результати визначення ТТГ, вільних $\mathrm{T}_{3} \mathrm{i} \mathrm{T}_{4}$. Із МЛ «ДІЛА»

$$
\text { तु }
$$

- немає потреби враховувати можливе приймання біотину пацієнтом;

- вірогідними є результати визначення ТТГ, вільних $\mathrm{T}_{4}$ i $\mathrm{T}_{3}$;

- упевненість у результатах досліджень, відсутність ризику неправильної діагностики, викликаної біотином.

Рекомендащї FDA щодо попередження інтерферуючого впливу препаратів біотину на хід лабораторних досліджень, 2017

Інтерференційний вплив біотину, Abbott

Diagnostics, 2017 